\title{
Changes in the thyroid hormone profiles in children with nephrotic syndrome
}

Sun Hee Jung, MD, Jeong Eun Lee, MD, Woo Yeong Chung, MD

Department of Pediatrics, Inje University Busan Paik Hospital, Inje University College of Medicine, Busan, Korea

Purpose: We compared thyroid hormone profiles in children with nephrotic syndrome (NS) during the nephrotic phase and after remission.

Methods: This study included 31 pediatric NS patients. The thyroid hormone profiles included serum levels of triiodothyronine (T3), thyroxine (T4), thyroid-stimulating hormone (TSH), and free T4.

Results: Of the 31 patients, 16 (51.6\%) showed abnormal thyroid hormone profiles: 6 had overt hypothyroidism, 8 had subclinical hypothyroidism, and 2 had low T3 syndrome. The mean serum T3, $\mathrm{T} 4$, and free T4 levels in the nephrotic phase and after remission were $82.37 \pm 23.64$ and $117.88 \pm 29.49$ $\mathrm{ng} / \mathrm{dL}, 5.47 \pm 1.14$ and $7.91 \pm 1.56 \mu \mathrm{g} / \mathrm{dL}$, and $1.02 \pm 0.26$ and $1.38 \pm 0.23 \mathrm{ng} / \mathrm{dL}$, respectively; the levels were significantly lower in the NS nephrotic phase ( $P=0.0007, P<0.0001$, and $P=0.0002)$. The mean serum TSH levels during the nephrotic phase and after remission were $8.05 \pm 3.53$ and $4.08 \pm 2.05 \mu \mathrm{lU} /$ $\mathrm{mL}$, respectively; they were significantly higher in the nephrotic phase $(P=0.0005)$. The urinary protein/ creatinine ratio during the nephrotic phase was significantly correlated with serum $\mathrm{T} 3, \mathrm{~T} 4$, and free $\mathrm{T} 4$ levels ( $r=-0.5995, P=0.0032 ; r=-0.5797, P=0.0047 ; r=-0.5513, P=0.0078$ ) as well as with TSH levels $(r=0.5022, P=0.0172)$. A significant correlation was found between serum albumin and serum T3 levels during the nephrotic phase $(r=0.5385, P=0.0018)$ but not between serum albumin and T4, TSH, or free T4 levels. These significant correlations all disappeared after remission.

Conclusion: Abnormal thyroid hormone profile findings were observed in $51.6 \%$ of pediatric patients with NS. Thyroid hormone levels normalized after remission, regardless of levothyroxine therapy.

Key words: Thyroid gland, Nephrotic syndrome, Thyroid hormones, Child

\section{Introduction}

Nephrotic syndrome (NS) is a glomerular disease that commonly affects children and is characterized by excessive urinary protein excretion. Proteinuria results from increased permeability of the glomerular capillary wall, and subsequent impaired reabsorption by the epithelial cells of the proximal tubule. It has been discovered that excretion of highmolecular-weight proteins (IgG, IgM) and low-molecular-weight proteins in urine is increased in the conditions of severe glomerular and tubular damage. ${ }^{1)}$ In a normal environment, lowmolecular-weight proteins are completely reabsorbed in the proximal tubule.

Excessive loss of urinary protein due to NS leads to loss of albumin and thyroxine binding globulin (TBG) through urine and can affect thyroid function. It also damages renal tubules and reduces the reabsorption of low-molecular-weight proteins, including free thyroid hormones. A reduction in the thyroid hormone reserve can increase the risk of hypothyroidism in patients with NS.

Only $0.02 \%-0.3 \%$ of circulatory thyroxines exist in the free-form, and most are bound to three types of proteins (molecular weight 50,000-70,000 Da); TBG is bound in the highest ratio,
Corresponding author: Woo Yeong Chung, MD, $\mathrm{PhD}$

Department of Pediatrics, Inje University Busan Paik Hospital, Inje University College of Medicine, 75 Bokji-ro, Busanjin-gu, Busan 47392, Korea

Tel: +82-51-890-6280

Fax: +82-51-895-7785

E-mail: chungwy@chol.com

https://orcid.org/0000-0002-5024-7285

Received: 22 August, 2018

Revised: 1 October, 2018

Accepted: 4 October, 2018

Copyright $(\odot 2019$ by The Korean Pediatric Society

This is an open-access article distributed under the terms of the Creative Commons Attribution NonCommercial License (http://creativecommons.org/ licenses/by-nc/4.0/n which permits unrestricted noncommercial use, distribution, and reproduction in any medium, provided the original work is properly cited. 
and prealbumin and albumin are also involved. ${ }^{2)}$ These proteins partially penetrate the glomerular membrane and are reabsorbed by megalin and cubilin in the proximal tubule. In a study evaluating normal renal handling of free thyroid hormones, free T4 was reabsorbed in the renal tubules, but free T3 was excreted. ${ }^{3-6)}$ Urinary thyroid-stimulating hormone (TSH) excretion increases as the serum TSH level increases. ${ }^{\text {?) }}$

Several studies have been conducted on thyroid hormone changes in patients with NS. ${ }^{8-14)}$ However, most have observed steroid resistant NS. Other factors besides heavy proteinuria may be involved in changes of the thyroid function. Long-term administration of steroids and other immunosuppressants can also affect the thyroid. Changes in the thyroid function are affected by complex factors, such as a decrease in the circulating thyroid hormone concentration, changes in the affinity to carrier proteins, a decrease in the tissue thyroid hormone content, and increased iodine reserve within the thyroid. Continued hyperthyroidism or hypothyroidism can lead to changes in markers of renal tubule function, or renal parameters, such as glomerular filtration rate (GFR), urine specific gravity, and urinary protein/creatinine (Cr) ratio. ${ }^{15)}$ We compared thyroid hormone profiles of pediatric patients with NS at nephrotic phase and after remission.

\section{Materials and methods}

\section{Material}

Patients who were diagnosed with NS at the Department of Pediatrics, Inje University Busan Paik Hospital, from January 2001 to December 2017 were included. During this period, 392 patients were diagnosed with NS. Among them, 318 have remission to standard steroid therapy within 8 weeks. Thirty-one patients were tested with thyroid hormone profiles both at nephrotic phase and remission. During the follow-up period, the number of patients was counted as one patient if the same patient had multiple relapses. If the same patient were tested with thyroid hormone profiles both several times and showed abnormalities even for one time, then he is considered having abnormal thyroid function. Among the patients included in this study 13 patients had a renal biopsy. Six patients had minimal change NS, 2 had mesangiocapillary-proliferative glomerulonephritis, 2 had membranous nephropathy, 2 had IgA nephropathy, and 1 had C1q nephropathy. The remaining 18 patients did not have a renal biopsy.

NS was diagnosed if a subject had generalized edema; hypoalbuminemia, defined as serum albumin $<2.5 \mathrm{~g} / \mathrm{dL}$ for ages less than 18 years; an early morning urinary protein/Cr ratio of $\geq 2.0$; or urinary protein levels $\geq 960 \mathrm{mg} / \mathrm{m}^{2} /$ day. Remission was defined as a negative to trace urine dipstick for proteinuria for 3 consecutive days or a spot urinary protein $/ \mathrm{Cr}$ ratio $<0.2{ }^{16)}$

Overt hypothyroidism was diagnosed for free T4 level $<0.93 \mathrm{ng} /$
$\mathrm{dL}$, and TSH level $>10 \mathrm{mIU} / \mathrm{L}$. Subclinical hypothyroidism was diagnosed when the free $\mathrm{T} 4$ level was within the normal range, but the TSH level was 5-10 mIU/L. Low T3 syndrome was diagnosed for normal free T4 and TSH levels, and T3 $<80 \mathrm{ng} / \mathrm{dL}$.

This study was approved by the Institutional Review Board of Inje University Busan Paik Hospital (approval number: 18-098). Informed consent was exempted for all subjects due to the retrospective study nature.

\section{Method}

The medical records of the patients were retrospectively reviewed. For 31 patients who were diagnosed with NS, serum total protein, albumin, total cholesterol, electrolyte levels, $\mathrm{Cr}$, and estimated glomerular filtration ratio (eGFR) were measured. In addition, thyroid hormone profiles were analyzed. The total 24-hour urinary protein excretion, or early-morning spot urinary protein/Cr ratio was measured.

The serum T3, T4, TSH, and free T4 levels were measured using the electro-chemiluminescence immunoassay (ECLIA) to assess the thyroid function. In the ECLIA, chemiluminescent ruthenium is used to electrically induce antigen-antibody reactions on the surface of steroptoavidin-coated paramagnetic micro-beads, and the luminescence emitted is measured to determine the concentration of the substance of interest. The Elecsys T3, Elecsys T4, Elecsys TSH, and Elecsys FT4 II kits from Roche Diagnostics Co., Ltd. were used. For the normal reference range, the normal range of each kit was used (range corresponding to the 2.5th-97.5th percentiles).

In addition, anti-thyroglobulin, anti-thyroid-stimulating hormone receptor antibody, and anti-thyroid peroxidase antibodies were measured in some patients with overt hypothyroidism.

\section{Statistical analysis}

All measurements and calculations are expressed as the mean \pm standard deviations. MedCalc statistical software (ver. 16.4.3, MedCalc Software bvba, Ostend, Belgium) was used for the statistical analyses. Between-group differences were assessed by the paired $t$ test and the Wilcoxon test for nonparametric distributions. Pearson correlation coefficient was used for correlation analysis between thyroid hormone profiles and serum albumin or urinary protein/Cr ratio. A $P$ value of $<0.05$ was considered to be statistically significant.

\section{Results}

\section{General patient characteristics}

Thirty-one pediatric patients with NS enrolled in this study, including 18 boys and 13 girls. The mean age at the initial diagnosis was $7.8 \pm 4.6$ years, and the mean age at the time of thyroid hormone profile analysis was $13.7 \pm 6.4$ years. 


\section{Biochemical and urine test result changes at the time of NS onset and remission}

Biochemical and urine test result changes at NS nephrotic phase and remission are shown in Table 1. The total serum protein level was $5.18 \pm 1.08 \mathrm{~g} / \mathrm{dL}$ at NS nephrotic phase and was significantly lower than the level at remission of $6.30 \pm 0.88 \mathrm{~g} / \mathrm{dL}(P<0.0001)$. The serum albumin level was also significantly lower at NS nephrotic phase $(2.39 \pm 0.50 \mathrm{~g} / \mathrm{dL})$ than at remission $(3.81 \pm 0.53 \mathrm{~g} / \mathrm{dL})(P<$ $0.0001)$. The total serum cholesterol level was significantly higher at NS nephrotic phase $(319.65 \pm 106.94 \mathrm{mg} / \mathrm{dL})$ than at remission $(221.97 \pm 46.70 \mathrm{mg} / \mathrm{dL})(P<0.0001)$. There was no significant difference in the serum $\mathrm{Cr}$ level and eGFR between the 2 groups. The serum calcium level was significantly lower at NS nephrotic phase $(8.24 \pm 0.64 \mathrm{mg} / \mathrm{dL})$ than at remission $(9.29 \pm 0.52 \mathrm{mg} / \mathrm{dL})(P<0.0001)$. The serum sodium level was significantly lower at NS nephrotic phase $(138.42 \pm 2.22 \mathrm{mEq} / \mathrm{L})$ than at remission $(140.58 \pm 1.67 \mathrm{mEq} /$ L) $(P=0.0001)$. There were no significant differences in the serum potassium, chloride, and phosphate levels between the 2 groups. The urinary protein/Cr ratio was significantly higher at NS nephrotic phase $(14.05 \pm 12.12)$ than at remission $(0.28 \pm 0.17)(P<0.0001)$.

\section{Changes of thyroid hormone profiles at NS onset and remission}

Of the 31 patients, 16 (51.6\%) showed abnormal findings in thyroid hormone profiles at nephrotic phase of NS. Six had overt hypothyroidism, 8 had subclinical hypothyroidism, and 2 had low T3 syndrome.

Changes of thyroid hormone profiles at NS nephrotic phase and remission are shown in Table 2. The mean T3 level was 82.37 \pm 23.64 $\mathrm{ng} / \mathrm{dL}$ at NS onset, and $117.88 \pm 29.49 \mathrm{ng} / \mathrm{dL}$ at remission. The mean T4 level was $5.47 \pm 1.14 \mu \mathrm{g} / \mathrm{dL}$ at NS onset, and $7.91 \pm 1.56 \mu \mathrm{g} / \mathrm{dL}$ at remission. The mean free T4 level was $1.02 \pm 0.26 \mu \mathrm{IU} / \mathrm{m}$ at NS onset, and $1.38 \pm 0.22 \mu \mathrm{IU} / \mathrm{m}$ at remission. Therefore, the mean thyroid

Table 1. Comparisons of biological data between nephrotic and remission phases in children with nephrotic syndrome

\begin{tabular}{lccr}
\hline Variable & $\begin{array}{c}\text { Nephrotic phase } \\
(\mathrm{n}=31)\end{array}$ & $\begin{array}{c}\text { Remission phase } \\
(\mathrm{n}=31)\end{array}$ & $P$ value \\
\hline Total protein & $5.18 \pm 1.08$ & $6.30 \pm 0.88$ & $<0.001$ \\
Albumin & $2.39 \pm 0.50$ & $3.81 \pm 0.53$ & $<0.001$ \\
Total cholesterol & $319.65 \pm 106.94$ & $221.97 \pm 46.70$ & $<0.001$ \\
Creatinine & $0.62 \pm 0.19$ & $0.56 \pm 0.15$ & 0.173 \\
eGFR & $141.92 \pm 14.85$ & $150.09 \pm 21.21$ & 0.084 \\
Sodium & $138.42 \pm 2.22$ & $140.58 \pm 1.67$ & 0.001 \\
Potassium & $4.34 \pm 0.57$ & $4.40 \pm 0.39$ & 0.630 \\
Chloride & $102.00 \pm 3.42$ & $102.92 \pm 2.82$ & 0.252 \\
Calcium & $8.24 \pm 0.64$ & $9.29 \pm 0.52$ & $<0.001$ \\
Phosphate & $4.44 \pm 0.82$ & $4.28 \pm 1.00$ & 0.494 \\
U Pro/Cr & $10.21 \pm 5.61$ & $0.28 \pm 0.17$ & $<0.001$ \\
\hline
\end{tabular}

Values are presented as mean \pm standard deviation.

eGFR, estimated glomerular filtration ratio; U Pro/Cr, urinary protein/creatinine. hormone levels were significantly lower at NS nephrotic phase $(P=$ $0.0007, P<0.0001$, and $P=0.0002$ ) compared than those of at remission, respectively. The TSH level was $8.05 \pm 3.53 \mathrm{ng} / \mathrm{dL}$ at NS onset, and $4.08 \pm 2.05 \mathrm{ng} / \mathrm{dL}$ at remission; the level was significantly higher at remission $(P=0.0005)$ compared than that of at remission.

\section{Correlations between urinary protein/ $\mathrm{Cr}$ ratio and serum thy- roid hormone profiles in children with NS at onset}

When correlating urinary protein/Cr ratio with thyroid hormone profiles, urinary protein/ $\mathrm{Cr}$ ratio negatively correlated with serum T3, T4, and free T4 levels $(r=-0.5995, P=0.0032 ; r=-0.5797, P=$ $0.0047 ; r=-0.5513, P=0.0067)$, respectively. The urinary protein/ Cr ratio positively correlated with serum TSH levels $(r=0.5022$, $P=0.0146$ ) (Table 3, Fig. 1). These significant correlations between urinary protein/Cr ratio and serum thyroid hormone profiles were all disappeared after remission.

\section{Correlations between serum albumin and serum thyroid hor- mone profiles in children with NS at onset}

When correlating serum albumin with thyroid hormone profiles, serum albumin correlated with serum T3 level $(r=0.5385, P=0.0018)$ (Table 4). However, no significant correlations were found between serum albumin and T4, TSH, or Free T4 levels. The significant correlation between serum albumin and serum T3 level was disappeared after remission.

\section{Treatment and progress}

Antibody tests were additionally performed for four of the 6 pati-

Table 2. Comparisons of the mean levels of thyroid hormones between the nephrotic and after remission phases in children with nephrotic syndrome and abnormal thyroid hormone profiles

\begin{tabular}{lccl}
\hline Thyroid hormone profile & $\begin{array}{c}\text { Nephrotic phase } \\
(\mathrm{n}=16)\end{array}$ & $\begin{array}{c}\text { Remission phase } \\
(\mathrm{n}=16)\end{array}$ & $P$ value \\
\hline T3 & $82.37 \pm 23.64$ & $117.88 \pm 29.49$ & 0.001 \\
T4 & $5.47 \pm 1.14$ & $7.91 \pm 1.56$ & $<0.001$ \\
TSH & $8.05 \pm 3.53$ & $4.08 \pm 2.05$ & 0.001 \\
Free T4 & $1.02 \pm 0.26$ & $1.38 \pm 0.23$ & 0.001
\end{tabular}

Values are presented as mean \pm standard deviation.

T3, triiodothyronine; T4, thyroxine; TSH, thyroid-stimulating hormone.

Table 3. Correlation analysis between urinary protein/creatinine ratio and serum thyroid hormone profiles in children with nephrotic syndrome at onset

\begin{tabular}{lccc}
\hline Thyroid hormone profile & Coefficient $r$ & Urinary Pro/Cr ratio 95\% $\mathrm{Cl}$ & $P$ value \\
\hline T3 & -0.5995 & -0.8151 to -0.2381 & 0.003 \\
T4 & -0.5797 & -0.8046 to -0.2092 & 0.005 \\
TSH & 0.5022 & 0.1022 to 0.7624 & 0.015 \\
Free T4 & -0.5513 & -0.7894 to -0.1689 & 0.007 \\
\hline
\end{tabular}

$\mathrm{Pro} / \mathrm{Cr}$, protein/creatinine; $\mathrm{Cl}$, confidence interval; $\mathrm{T} 3$, triiodothyronine; $\mathrm{T4}$, thyroxine; TSH, thyroid-stimulating hormone. 

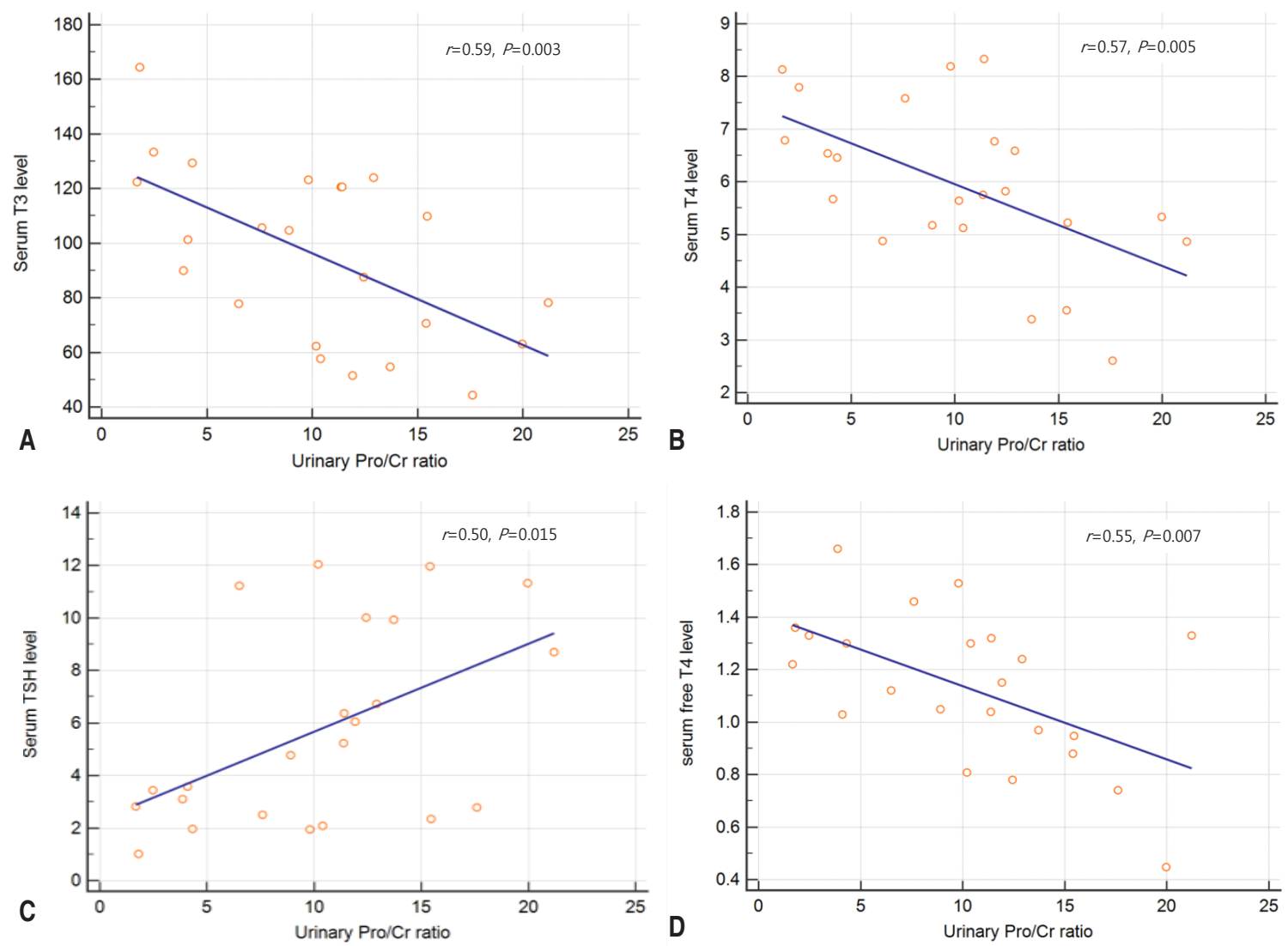

Fig. 1. Correlation between urinary protein/creatinine ratio and thyroid hormone profiles (A, serum T3 level; B, serum T4 level; C, serum TSH level; D, serum free T4 level) in children with nephrotic syndrome at nephrotic phase in all the studied subjects. T3, triiodothyronine; T4, thyroxine; TSH, thyroid-stimulating hormone; Pro/Cr, protein/creatinine.

Table 4. Correlation analysis between serum albumin and thyroid hormone profiles in children with nephrotic syndrome at onset

\begin{tabular}{lccc}
\hline Thyroid hormone profile & Coefficient $r$ & Serum albumin $95 \% \mathrm{Cl}$ & $P$ value \\
\hline T3 & 0.54 & 0.23 to 0.75 & 0.002 \\
T4 & 0.27 & -0.09 to 0.57 & 0.135 \\
TSH & -0.26 & -0.56 to 0.10 & 0.155 \\
Free T4 & 0.19 & -0.18 to 0.51 & 0.305
\end{tabular}

$\mathrm{Cl}$, confidence interval; T3, triiodothyronine; T4, thyroxine; TSH, thyroidstimulating hormone.

ents who had overt hypothyroidism. All 4 patients showed normal results. Five patients were administered $0.1 \mathrm{mg}$ of levothyroxine for 20-90 days. One patient was not administered levothyroxine. The patients who were administered levothyroxine sustained normal thyroid function after discontinuation of levothyroxine. Thyroid hormone profiles returned to normal for other patients who had subclinical hypothyroidism or low T3 syndrome after remission without levothyroxine therapy.

\section{Discussion}

Changes in the thyroid hormone profiles were observed in 51.6\% of all patients at NS onset in this study. Six had overt hypothyroidism, eight had subclinical hypothyroidism, and 2 had low T3 syndrome. For patients who had multiple relapses of NS, if the patient showed abnormal thyroid hormone levels, then he is considered having abnormal thyroid function. For this reason, the reported incidence of abnormal thyroid function in NS patients may be higher than the actual incidence. For example, in the case of a 12-year-old girl who experienced 5 relapses, the patient had normal thyroid hormone profiles at the time of 4 relapses and showed an elevated TSH level during only 1 relapse time. A 15-year-old girl who experienced three relapses had overt hypothyroidism in every relapses and repeatedly took levothyroxine. As can be seen, various changes in the thyroid hormone profile were observed even in a single patient depending on each NS relapse. The incidence of abnormal thyroid function of pediatric NS patient in this study was similar to that of reported by a single center study by Guo et al. ${ }^{14)}$ of $44.51 \%$.

Ito et $a .^{10)}$ reported the amount of proteins excreted in urine to positively correlate with urinary $\mathrm{T} 3$, $\mathrm{T} 4$, free $\mathrm{T} 3$, free $\mathrm{T} 4$, and TBG, 
and negatively correlate with serum T3, T4, Free t3, free T4, and TBG levels. Studies have also reported serum albumin and serum TSH to be negatively correlated. ${ }^{10,14)}$ In this study, the urinary protein/ Cr ratio significantly correlated with serum T3, T4, TSH, and free T4 levels at NS onset. However, a significant correlation was found only between serum albumin and T3 levels at NS nephrotic phase.

Because we did not measure the amount of T3, T4, TSH, and free T4 excreted in urine, we could not clearly identify the mechanism by which the risk of hypothyroidism increases at NS onset. However, it can be deduced that the increased loss of protein-unbound (free) and protein bound thyroid hormones in urine in the presence of excessive proteinuria may a major risk factors of hypothyroidism. This is supported as thyroid hormone levels spontaneously returned to normal after a remission of proteinuria, regardless of levothyroxine administration. The fact that a significant correlation was only observed between serum albumin and serum T3 levels at NS onset suggests that other additional factors such as the treatment duration and type of immune suppressive agents, conversion ability from T4 to T3 and compensatory mechanisms of the thyroid due to NS may be involved besides urinary loss. The possibility of tubulointerstitial injury due to temporary renal damage cannot be eliminated. It is a well-established that renal damage leads to renal tubule damage, and this reduces the reabsorption of LMW proteins, and can affect thyroid functions. In addition, the incidence of hypothyroidism increases as the GFR decreases. ${ }^{17,18)}$

Very few studies have been conducted on the need for levothyroxine administration in patients with hypothyroidism caused by NS, and there are no established treatment principles for this condition. ${ }^{8,11,14)}$ However, it has been reported that the dose of levothyroxine must be increased in patients currently taking levothyroxine due to hypothyroidism when they develop NS. ${ }^{19,20)}$

There were almost no changes in GFR and serum $\mathrm{Cr}$ levels before and after remission who have abnormal thyroid function. This crosssection study has some limitations. It had a small sample size, did not measure free $\mathrm{T} 3$ in the serum thyroid hormone profile, and did not measure the total amount of urinary loss of thyroid hormones. Once the mechanism of hypothyroidism in NS is established through large-scale prospective studies, it may be possible to establish a reasonable basis for the need of levothyroxine administration.

In conclusion, Thyroid hormone profile abnormal findings were observed in $51.6 \%$ of pediatric patients with NS in this study. Thyroid hormone levels normalized after remission, regardless of levothyroxine therapy

\section{Conflicts of interest}

No potential conflict of interest relevant to this article was reported.

\section{References}

1. D’Amico G, Bazzi C. Pathophysiology of proteinuria. Kidney Int 2003;63:809-25.

2. Schussler GC. The thyroxine-binding proteins. Thyroid 2000;10:1419.

3. Faber J, Siersbaek-Nielsen K, Kirkegaard C. Renal handling of thyroxine, 3,5,3'- and 3,3',5'-triiodothyronine, 3,3'- and 3',5'-diiodothyronine in man. Acta Endocrinol (Copenh) 1987;115:144-8.

4. Orden I, Pie J, Juste MG, Marsella JA, Blasco C. Thyroxine in unextracted urine. Acta Endocrinol (Copenh) 1987;114:503-8.

5. Faber J, Busch-Sørensen M, Rogowski P, Kirkegaard C, SiersbaekNielsen K, Friis T. Urinary excretion of free and conjugated 3',5'diiodothyronine and 3,3'-diiodothyronine. J Clin Endocrinol Metab 1981;53:587-93.

6. Burke CW, Shakespear RA. Triiodothyronine and thyroxine in urine. II. Renal handling, and effect of urinary protein. J Clin Endocrinol Metab 1976;42:504-13.

7. Yoshida K, Sakurada T, Kaise K, Kaise N, Nomura T, Itagaki Y, et al. Measurement of thyroid stimulating hormone (TSH) in human urine. Endocrinol Jpn 1988;35:733-9.

8. Kapoor K, Saha A, Dubey NK, Goyal P, Suresh CP, Batra V, et al. Subclinical non-autoimmune hypothyroidism in children with steroid resistant nephrotic syndrome. Clin Exp Nephrol 2014;18:113-7.

9. Feinstein EI, Kaptein EM, Nicoloff JT, Massry SG. Thyroid function in patients with nephrotic syndrome and normal renal function. Am J Nephrol 1982;2:70-6.

10. Ito S, Kano K, Ando T, Ichimura T. Thyroid function in children with nephrotic syndrome. Pediatr Nephrol 1994;8:412-5.

11. Dagan A, Cleper R, Krause I, Blumenthal D, Davidovits M. Hypothyroidism in children with steroid-resistant nephrotic syndrome. Nephrol Dial Transplant 2012;27:2171-5.

12. Fonseca V, Thomas M, Katrak A, Sweny P, Moorhead JF. Can urinary thyroid hormone loss cause hypothyroidism? Lancet 1991;338:475-6.

13. Afroz S, Khan AH, Roy DK. Thyroid function in children with nephrotic syndrome. Mymensingh Med J 2011;20:407-11.

14. Guo QY, Zhu QJ, Liu YF, Zhang HJ, Ding Y, Zhai WS, et al. Steroids combined with levothyroxine to treat children with idiopathic nephrotic syndrome: a retrospective single-center study. Pediatr Nephrol 2014;29:1033-8.

15. van Hoek I, Daminet S. Interactions between thyroid and kidney function in pathological conditions of these organ systems: a review. Gen Comp Endocrinol 2009;160:205-15.

16. Hogg RJ, Portman RJ, Milliner D, Lemley KV, Eddy A, Ingelfinger J. Evaluation and management of proteinuria and nephrotic syndrome in children: recommendations from a pediatric nephrology panel established at the National Kidney Foundation conference on proteinuria, albuminuria, risk, assessment, detection, and elimination (PARADE). Pediatrics 2000;105:1242-9.

17. Lo JC, Chertow GM, Go AS, Hsu CY. Increased prevalence of subclinical and clinical hypothyroidism in persons with chronic kidney disease. Kidney Int 2005;67:1047-52.

18. Rhee CM. The interaction between thyroid and kidney disease: an overview of the evidence. Curr Opin Endocrinol Diabetes Obes 2016; 23:407-15.

19. Benvenga S, Vita R, Di Bari F, Fallahi P, Antonelli A. Do not forget nephrotic syndrome as a cause of increased requirement of levothyroxine replacement therapy. Eur Thyroid J 2015;4:138-42.

20. Soh S, Aki O, Manabu 0, Norimasa K, Hiroshi K, Masao N. A case of minimal change nephrotic syndrome with hypothyroidism deterioration. CEN Case Rep 2016;5:95-8. 